\title{
Computerization of the Norwegian Land Register: An Early Example of Outsourcing and Still a Model for Good Practice
}

\author{
Bjørn Nagell \\ Devoteam daVinci \\ bjorn. nagell@devoteam.com
}

\begin{abstract}
Computerization of the Ground Book and the property rights registration, led to a major improvement of the service quality. The computerizing, which started in the late 1980s, resulted in considerable cost savings for the government, citizens, banks, real estate agents, and other private enterprises using the register. At the time, the government made a bold decision to outsource the total effort to private consortium. The author reflects on some experiences from this successful implementation of new computer-based services for the registration and publication of property rights.
\end{abstract}

Keywords: Digitalization, e-government, outsourcing, public administration.

\section{Historical Background}

The disposal of real estate property is one of the most basic rights in all countries. Scandinavia, including Norway, Denmark, Sweden and, to some extent, Finland, have very similar traditions developed through trade and cultural exchange across borders for more than a thousand years.

During the Viking period, the old courts were called, "Tinget," and Tinget announced a declaration of rights related to land. Since that time, the announcement of property rights was part of the court system. A law regulation in 1633 required the registration of such announcements. This led to the establishment of the first land register in 1665, which contained most real estate properties in Norway, including information about the user of the land and his tax liability.

Two hundred years later, a new law established the existing land register, the Ground Book (GB). In this register, both a block and a parcel number defined the properties, an identification that is still in use today. The old Ground Book had one page per property defined by block and parcel number, and it contained information on the title and other rights related to it.

\section{The Purpose of Registration}

Individuals, companies, the government, or joint ownership could hold title to the land. In addition, a separate law regulates leasehold. The rights to real estate 
properties can serve as security for loans. Consequently, a mortgage deed would be registered as a financial encumbrance on the property, which could limit the owner's right of use of the land such as the right of first refusal if the property is sold, right of way, and the right to hunt, among others.

Before someone buys an asset or takes an asset as security for a loan, it is important to be able to check

○ that the one who sells the object or gives it as security has the right to do so

o whether the object has already been used as collateral for loans from other sources, and

o that there is no other encumbrance or restriction that might limit the rights to dispose of the object or reduce its value.

It is important that such information is available to the public so that potential buyers and lenders can easily search for such information prior to purchase.

\section{The Need for Computerization}

During 1985, approximately 1.1 million transactions were entered into the manual land register. Of this total, 120 to 140 thousand transactions were transfers of title. The annual growth that year was 11 percent compared with an average of 3 percent growth over the last ten years. The number of requests for information from the register in 1986 was estimated at 2.6 million per year:

- Certified extracts from the books:

30,000 per year

O Uncertified extracts from the books:

600,000 per year

- Questions by phone or from visitors to the office: 2,000,000 per year

While the courts experienced a heavy workload, the public experienced problems with long processing times for the transactions - more than thirty days on average. The government considered additional personnel; but at the same time a need to bring the Ground Book up-to-date, including reorganizing and restructuring the information in the books had been identified. Therefore, they decided to introduce modern information technology to improve the efficiency and quality of the registration. The idea of computerizing the books was expected to improve the current situation and lead to major cost savings.

Making information available online meant a value-added service for which the external users should be willing to pay. In this way, the distribution of digital information from the land register represented a business opportunity that could provide financing for the implementation of computer technology in the local courts.

\section{Implementation Strategy}

The planning of a computerized land register started in 1984. During this stage, the Ministry of Justice (MOJ) identified three critical factors for which it had to make provisions; these include: 
o The implementation required a large project and the government did not have the staff, skills, and experience to carry out such a major enterprise,

o The introduction of information technology should be carried out for the land register and include the computerization of all the courts at the same time.

o Sources of financing should be sought outside the government budgets. External users (banks, insurance companies, real estate agents) would benefit from increasing the speed and reliability of the transfer of title and financing.

Initially, through their National Commercial Bank Association, the MOJ proposed, that the Norwegian banks could take on the register project as a joint venture, since they would be major users of a mortgage register. After some discussions, the Bank Association refused the offer.

\section{The Contract - Terms and Conditions}

The MOJ decided to issue an invitation to major information technology companies for open tenders for a national land register system. The tenders should include systems development, equipment and communication, conversion of manual books, training, operation, as well as maintenance and support. In return, the contractor would receive a part of the fees for registration and requests for information from the register.

Thus, the contractor had the right to commercialize the information within certain market segments. The contract period defined a timeframe that would give the bidders a reasonable return on their investments. However, the MOJ had the possibility to terminate it at any time; in doing so, however, they would then have to repay the other party their investments including interest. The MOJ also had an option to take certain corrective actions if the profitability proved to be far above expectations. The MOJ kept the ownership of the register database.

The terms of reference specified the following tasks related to the land register (GB):

O Introduction of a system with the necessary registration and report functions to produce the Ground Book (GR), the journal of transactions, certified printout of encumbrances, and other information on registered documents according to the Norwegian Law for Legal Registration,

- Establishment of an accounting system for the collection of fees for registration and use of information from the database,

○ Conversion of the paper files.

In addition, one important task was the implementation of general office automation systems for the local courts. Through separate agreements with the MOJ, the contractor would supervise the installation of computer equipment and provide user, maintenance, and operational support.

\section{Organization}

Because of the procurement process, the contract was awarded to a joint venture between Statens datasentral (SDS) and Kommunedata (KD) through Tinglysningsdata 
AS (TD), founded in 1987. In 1994, the organization changed its name to Norsk Eiendomsinformasjon AS (NE). Tinglysningedata had the following business idea:

- Assure that the court system in Norway utilized IT in the most efficient way

- Produce a reliable and easily accessible Ground Book, which could be used for the purpose of economical assessment of individuals and companies, available to the public

The TD was supposed to stay small and to concentrate on project management and other key functions. Most of the project was subcontracted, mainly to the owners. The mother companies carried the necessary guarantees for the fulfillment of the contract.

KD owned 60 percent of TD and SDS owned 40 percent, with a share capital of six million NOK. Both of these companies were major providers of data processing services, including the operation of nationwide computer networks. KD was a joint venture of seven regional computer centers owned by municipalities. Later, the regional centers merged and privatized into two separate companies-NIT and Allianse. SDS was a government owned share holding company, originally established to provide data processing services for the central government.

The MOJ retained a strong controlling and monitoring position, but it avoided taking part in the day-to-day management. Representatives for the MOJ held two positions on the board of directors. In addition, a steering committee had a cocoordinating role.

\section{The Implementation Project}

The technical solution consisted of the following main elements:

o Each local court received a UNIX server with workstations in a local area network used for registration. Each local system kept a complete copy of the register for the actual court district. There was 100 percent terminal coverage in the court system.

- A centralized database on a mainframe computer comprised the legal place of record. The daily transaction data transferred to the central database, which was updated each day.

o The local court using the local system to download printouts from the central system issued all authorized extracts from the GB. All phone or counter inquiries were answered by accessing the local database.

o The central database had gateways to the distributors' value added networks giving external users access to information.

When the implementation project was finished, 120 servers and 1,500 workstations were installed in 102 local courts, providing a 100 percent terminal coverage.

Providing information and training to all court personnel was regarded a key factor for success. A total of twelve thousand days of training was given through the project to government employees, distributors, and customers. A first class support service was also essential for the success of the project. A technical group of seven people provided hotline telephone support; they answered eleven thousand inquiries in 1993. 


\section{Conversion of Manual Books}

The conversion ensured that the required information from the manual books was transferred into the new system with the right structure and quality, but the court system did not have the capacity to take on any additional workload. They were already behind with current tasks.

Then, the conversion was organized as a project. Four conversion centers were established in different rural areas of Norway with high unemployment rates. Each center comprised approximately twenty-five people. The local court offices thus had a temporary increase in their workload, taking on training and dedicating some key people to support the project. They also had a peak work period when the results of the conversion were under approval. However, at this stage they were using computers for all new registrations, thus taking advantage of the improved efficiency.

Initial estimates showed that conversion of full text from the manual book would require 4 kbyte of storage per property. The use of codes and secondary files for the corresponding textual description reduced the registration volume to half. During the project, the daily production was 2,700 properties per day, which was somewhat more than they estimated.

The conversion started in 1988 and it included 2.4 million properties in 97 local courts. It required an average of four months to complete one local court. The conversion centers accomplished their tasks in 1993; the centers closed down as the workload reduced.

\section{Marketing and Distribution}

From the beginning, the strategy had been to work solely through distributors. TD put much effort into marketing and external information, because they needed it to educate the market and develop the demand for the services provided.

Active marketing started in 1989. Advertising material was produced aiming at professional users in the financial industry, the public in general, and the government. Newspaper advertisements had little effect; better results were obtained from using courts to inform and encourage customers to go online, and advertisements in professional magazines.

Market surveys were conducted to identify needs and test various pricing policies and institutions with large potential customers, such as commercial banks and local tax collection offices. A market poll of users in October 1990 showed that 90 percent were very satisfied. At that point, there were 800 customers, of whom 70 percent were bank and finance and 30 percent were insurance and government.

A number of PR activities were carried out including participation in meetings, conferences for customers and contact with associations for various customer groups. As many as 30 seminars with 400-500 participants were arranged for customers and salesmen from the distributors. In addition, TD established an incentive program for the salesmen.

By the end of 1993, TD's market coverage was 60 percent of all requests for information from the land register; the rest was inquiries directly to the courts. The 
financial market (banks, insurance, financing and credit information providers) represented 80 percent of this traffic.

\section{Financing}

Actual revenues followed the projected pattern over the first three years, but were delayed by one year. The reasons were a combination of three factors:

(a) The downturn of the real estate market in 1989-1992 led to a decrease of volume by 27 percent over the three years. Then the market started to rise again.

(b) It took longer than anticipated to get the financial market to start using the services. This was partly due to necessary changes of systems and working procedures, and partly related to the rate of conversion. The volume of transactions increased significantly after the completion of about two thirds of the conversions.

(c) The development after five years of operation far exceeded expectations. However, the increase in volume might have been even higher with lower transaction charges, although the market did not seem to be very price sensitive with regard to the level of fees imposed.

\section{Refinancing Government Buyout}

In 1992, Tinglysningsdata A/S was on the edge of bankruptcy and the government had taken it over. The project had progressed according to the plans and the costs were close to budget. However, revenues did not develop as anticipated, mainly due to market conditions, which led to a situation where the company had to obtain additional funding. The owners asked the government to increase TD's share of the legal fees and made this a condition for providing additional funding. Instead, the government decided to buy the company and to compensate existing owners. TD was the owner of all the local computer equipment and the workstations in the courts. The MOJ transferred title of equipment to the government and paid all debts.

However, the current organization of the project was running so well that no one would take the risk of disturbing its ongoing activities. Therefore, the MOJ decided not to change TD until the project was completed.

Because the government was criticized for involving the ordinary administrative tasks of running the court system with those of providing services to the public on a commercial basis, it was decided to divide the further financing into two separate activities.

A. Distribution of online information: TD retained the exclusive right to sell information from the register and had to bear all costs involved with the marketing and distribution of online services and the computer operation related to these activities.

B. Computerization of government activities: The MOJ paid separately all services related to the computerization of the court system according to a management contract. 
The MOJ also received criticism for having officers on the board of directors, because it meant combining responsibilities for the administrative and controlling role with the tasks of operational issues. Because of this criticism, a general policy was introduced restricting ministry representatives from sitting on the board of directors of a company. The ministry should execute its control solely through the owners' meetings and its power to appoint the board of directors.

On the other hand, we should note that the success of the project was largely due to such mixed roles by which the few people involved from the MOJ were able to control efficiently the implementation and secure coordinating activities. In this role, representatives of the MOJ could simultaneously design the concept, propose the required legal adjustments, instruct the court system, and control the project management.

\section{After Refinancing}

By 1993, after completion of the implementation project, the organization was left with the tasks of normal operations and support. At this point, the MOJ started to discuss alternative ways of organizing the activities in the future.

From 1987 to 1994, TD had twenty-six employees of which sixteen were part-time or contracted. On 1 January 1995, they transferred all support for the local courts, and the personnel involved in this, was transferred to a new agency (RIFT) established to provide training and support to all organization units under the MOJ's jurisdiction. RIFT was also responsible for acquisition, development, implementation, maintenance, and support for systems used in the legal sector of the government, including the local land register systems.

Thereafter, TD was purely dedicated to the task of operating, maintaining and supporting the central register, including the distribution of information from the register on a commercial basis. The company was also given the operation of the GAB register ${ }^{1}$ on behalf of the Ministry of Environment, which was the start of diversification into new and related services.

They kept the organization small and transparent. Most activities ware outsourced to subcontractors for a limited term, which keeps costs low due to market competition. By 1 January 1995, TD's staff comprised eleven people. The MOJ was the sole owner and the only participant at the owner's meeting.

\section{Costs and Benefits}

The cost of local equipment was around 70 million NOK and included 1,600 terminals and the necessary site computers for the whole court system, of which only 350 terminals were used for registration.

The cost of software development is difficult to estimate, but probably amounts to 15-20 million NOK including systems for local registration, central database register, and conversions. In addition, it included software for case handling, office automation, and a general accounting system. 
The total costs of conversion were approximately 160 million NOK. These costs were mainly expenses paid to subcontractors who were responsible for the establishment, operation, and dismantling of the four temporary conversion centers.

If the operation had continued according to its original form in private hands, the profit would have stabilized around 22 million NOK from 1993, with a turnover of about 65-70 million NOK (more than 30 percent), which means a repayment period of fifteen years for the project, excluding financial costs.

The time to register a transaction was reduced from 30 to 1.2 (1.4) days. Already in 1990, it was found that phone calls to the registry office at the local court had been reduced by 75 percent when the information became available online.

In 1987, 350 people were working with land registration in the local courts. Based on experience obtained in a trial project at a local court, the introduction of a computerized system would make it possible to handle the expected growth of transaction volume with the same number of employees.

The MOJ conducted a study in 1993 to measure benefits of the computerization, when the conversion was completed and the system was fully operating. The result of this analysis showed an improvement in efficiency of 30 percent for the land register activities.

One has to remember that the project also included financing the computerization of the whole court system. The income from registration fees, from which the project received a small part during implementation, covered more than twice the cost of registration and brought in another 250 million NOK per year for the government.

The savings within registration in the local courts was 30 percent, which meant a further 40 million NOK per year in addition to the annual profit from online sales. With such a total amount from profit and productivity gains, the repayment time was four years from completion of the implementation project.

\section{Learning Experience}

We must regard the entire project for the computerization of the Ground Book and the courts a success story. Outsourcing of the whole process was a bold decision initiated by some leading civil servants in the Ministry of Justice. The contractual model that was developed proved to work well for the government and made it possible to deal with the experienced problems in an adequate way. It is most likely that the project would also have been successful, even if it had survived in private hands.

Time and cost estimates turned out to be in the right range, the projected income was delayed for a year due to several factors. Nevertheless, the business case proved to be sound. One factor that was underestimated was the time it takes to introduce new services that radically change current working procedures for the users.

Since 2010, all registrations in the Ground Book are centralized, which could have taken place from the very beginning and would have increased the overall reduction of operating costs. However, if the registration activities had been removed from the court, the remaining tasks in many of the courts would have been below critical mass for these local institutions and would have initiated an even more comprehensive reform. Due to the political situation at that time, this would have been extremely difficult to accomplish. 
After the recent centralization of the Ground Book with the Norwegian Mapping Agency, the original mission of Norsk Eiendomsinformasjon is less important. However, Norsk Eiendomsinformasjon is still a vital institution under the jurisdiction of the Ministry of Trade and Industry, having diversified with other services related to the former ones.

\section{References}

1. Nagell, B.: Establishment of Property Right Registries in IDA Countries: A Framework for Development Based on Concepts and Experiences from Norway (1997)

2. Forespørsel om tilbud på et landsomfattende system for tinglysning, Justisdepartementet 19/6-1986

3. Årsberetninger i Tinglysningsdata A/S

4. En eiendomssaga 1987-1997. Et jubileumsskrift utgitt av Norsk Eiendomsinformasjon

5. Ejendomsregistrering $\mathrm{i}$ de nordiske lande: Et samarbeid mellom faginstitusjoner og universiteter i Norden; ISBN: 87-7866-412-8 